\title{
Kepatuhan Wajib Pajak UMKM: Pengetahuan Pajak, Sanksi Pajak, dan Modernisasi Sistem
}

\author{
Afuan Fajrian Putra ${ }^{1}$
}

${ }^{1}$ Universitas Islam Indonesia, D. I. Yogykarta, Indonesia

\section{INFO ARTIKEL JEL Classification :}

H25, D90

\section{Keywords :}

tax compliance, taxprayer, msme

\begin{abstract}
This research aims to examine the factors that have an influence on tax compliance. The independent variables used in this study are the variables of tax knowledge, tax sanctions, and tax modernization that will be tested partially and simultaneously on their influence on tax compliance. This study will examine these factors both simultaneously and partially. The population of this study is all MSMEs registered in the Office of Cooperatives, Small and Medium Enterprises, Sleman Regency. While the determination of the number of samples in this study using the Slovin formula and obtained the results of 100 respondents. However, not all data can be processed but as many as 85 respondents. Data collection techniques used in this study were to use a questionnaire and data analysis methods using multiple regression with analysis tools using SPSS version 16. The results of this study indicate that partially and simultaneously variables of tax knowledge, tax sanctions, and modernization have a significant effect on MSME tax compliance.
\end{abstract}

\begin{abstract}
ABSTRAK
Penelitian yang dilakukan ini bertujuan untuk menguji faktor-faktor yang memiliki pengaruh terhadap kepatuhan pajak. Variabel independen yang digunakan dalam penelitian ini adalah variabel pengetahuan pajak, sanksi pajak, dan modernisasi pajak yang keseluruhannya akan diuji pengaruhnya baik secara parsial maupun simultan terhadap kepatuhan pajak. Populasi dari penelitian ini adalah seluruh UMKM yang terdaftar di Dinas Koperasi, Usaha Kecil, dan Menengah Kabupaten Sleman. Sedangkan penentuan jumlah sampel dalam penelitian ini menggunakan rumus Slovin dan didapatkan hasilnya sebanyak 100 responden. Akan tetapi tidak semua data dapat diolah melainkan sebanyak 85 responden. Teknik pengambilan data yang dilakukan dalam penelitian ini adalah menggunakan kuesioner dan metode analisis data menggunakan regresi berganda dengan alat analisis menggunakan SPSS versi 16 . Hasil dari penelitian ini menunjukkan bahwa secara parsial dan simultan variabel pengetahuan pajak, sanksi pajak, dan modernisasi berpengaruh signifikan terhadap kepatuhan pajak UMKM.
\end{abstract}

\section{Pendahuluan}

Pajak menjadi salah satu bagian yang terpenting dalam menjalankan aktifitas pemerintahan di seluruh dunia ini termasuk di Indonesia. Pajak diposisikan sebagai faktor utama penggerak aktivitas dan program dari 
pemerintah. Hal ini disebabkan karena pajak menjadi bagian yang utama dalam sumber penerimaan negara. Peneriman pajak tersebut nantinya akan digunakan untuk kepentingan negara antara lain kepentingan untuk menjalankan program-program pemerintahan yang tujuan akhirnya adalah dapat dinikmati oleh masyarakat atau rakyat yang sudah berkontribusi terhadap pajak tetapi masyarakat atau rakyat secara luas. Oleh karena itu pemerintah saat ini menfokuskan dan menitikberatkan pada pemaksimalan penerimaan dari sektor pajak. Jika penerimaan pajak tidak bisa maksimal maka bisa dibayangkan bahwa nantinya programprogram yang sudah dirancang oleh pemerintah akan mengalami kendala dalam hal keuangan.

Data menunjukkan bahwa penerimaan pajak di Indonesia selama 10 tahun terakhir ini selalu dibawah target yang sudah ditetapkan diawal. Ketidaktercapainya penerimaan pajak tersebut bisa disebabkan karena penetapan target penerimaan pajak yang dilakukan oleh Pemerintah terlalu tinggi atau bisa juga disebabkan karena kesadaran dari Wajib Pajak untuk patuh terhadap ketentuan perpajakan yang masih rendah (Rustiyaningsih, 2011; Siahaan, 2013; Yanah, 2013; Budiningrum, 2014; Yogatama, 2014; Putri, 2014; Handayani, 2015; Putra, 2017; Putra \& Osman, 2019). Hal ini menjadi tugas berat bagi Direktorat Jenderal Pajak selaku pihak yang berwenang terhadap pajak untuk lebih aktif lagi agar dua faktor tersebut bisa terselesaikan.

Direktorat Jenderal Pajak sudah membuat dan melakukan kebijakan-kebijakan yang bertujuan memaksimalkan penerimaan pajak. Beberapa diantaranya adalah perubahan sistem pajak dari Official Assessment System ke Self Assessment System yang mana sistem tersebut memberikan kewenangan sepenuhnya terhadap pembayar pajak. Selain itu program Tax Amnesty yang berfungsi memberikan keringanan kepada Wajib Pajak tertentu. Kemudian kebijakan tentang penurunan tarif pajak dari $1 \%$ ke $0,5 \%$ untuk pelaku UMKM yang betujuan agar Wajib Pajak UMKM tidak merasa terbebani dan diringankan atas beban pajaknya.

Sektor UMKM mempunyai potensi yang sangat besar terhadap penerimaan pajak negara. Data menunjukkan bahwa kontribusi
UMKM terhadap Produk Domestik Bruto (PDB) Indonesia sebesar 60,34\% selama lima tahun terakhir. Selain menyumbang PDB, sektor UMKM juga mempunyai kontribusi dalam serapan tenaga kerja sebesar 97,22\%. Hal ini menunjukkan bahwa sebagian besar perekonomian di Indonesia didominasi pada sektor UMKM. Selain itu dilihat dari segi kuantitas atau jumlah UMKM di Indonesia yang terdaftar di Kementerian Koperasi dan Usaha Kecil dan Menengah sampai tahun 2017 adalah sebesar 59.697.827 (Putra \& Osman, 2019). Oleh karena itu kuantitas yang besar ini dapat menjadi potensi dan peluang yang bagus bagi penerimaan pajak. Akan tetapi potensi yang besar tersebut mempunyai tantangan yang sangat besar pula, salah satunya adalah menumbuhkan kesadaran Wajib Pajak UMKM untuk taat terhadap ketentuan perpajakan karena kontribusi dari sektor UMKM masih tergolong rendah yakni hanya 5\% dari total sumber penerimaan pajak.

Menumbuhkan kesadaran Wajib Pajak bisa dilakukan dengan cara memberikan edukasi atau pengetahuan tentang kewajiban perpajakan bagi setiap warga negara Indonesia. Faktor pengetahuan terhadap perpajakan tersebut menjadi langkah awal bagi Wajib Pajak untuk mematuhi ketentuan peraturan perpajakan. Wajib Pajak akan cenderung mematuhi ketentuan peraturan perpajakan dikarenakan tingkat pengetahuan tersebut memberikan arahan dan akan mendorong kearah kepatuhan.

Selain itu informasi tentang adanya sanksi pajak dapat juga digunakan untuk meningkatkan kepatuhan Wajib Pajak. Hal tersebut manjadi konsekuensi atas ketidakpatuhan terhadap ketentuan peraturan perpajakan. Konsekuensi tersebut dapat berupa sanksi mulai dari yang bersifat administratif sampai yang bersifat pidana. Pemberian sanksi ini dapat mendorong kepatuhan Wajib Pajak karena orang cenderung takut ketika ada ancaman sanksi yang diberikan sebagai bentuk konsekuensi atas ketidakpatuhan. Modus yang dilakukan oleh Wajib Pajak biasanya berupa ketidakjujuran dalam melaporkan pajaknya. Modus tersebut juga mempunyai hubungan dengan pengetahuan Wajib Pajak tentang ketentuan perpajakan karena ketidakjujuran tersebut disebabkan karena pengetahuan Wajib Pajak tentang ketentuan perpajakan sangatlah 
terbatas. Ketidakpahaman tersebut menjadikan Wajib Pajak untuk berpotensi mendapatkan sanksi pajak.

Cara lain yang dapat mendorong tingkat kepatuhan Wajib Pajak adalah melakukan modernisasi sistem pelaporan perpajakan. Pembaharuan tersebut diharapkan mempunyai dampak secara langsung bagi Wajib Pajak sehingga Wajib Pajak merasa bahwa sistem pelaporan pajak menjadi lebih mudah. Akan tetapi faktanya kepatuhan Wajib Pajak masih menjadi persoalan yang sering dihadapi oleh Direktorat Jenderal Pajak. Sehingga antara pengetahuan pajak, sanksi pajak, dan modernisasi sistem menjadi satu kesatuan yang mempunyai hubungan langsung pada kepatuhan pajak.

Berdasarkan penjelasan diatas, maka pertanyaan untuk penelitian ini antara lain apakah pengetahuan pajak, sanksi pajak, dan modernisasi sistem berpengaruh positif baik secara parsial maupun secara simultan terhadap kepatuhan Wajib Pajak UMKM di Kabupaten Sleman. Selain itu penelitian ini bertujuan untuk menguji pengetahuan pajak, sanksi pajak, dan modernisasi sistem secara parsial dan simultan terhadap kepatuhan Wajib Pajak UMKM di Kabupaten Sleman.

\section{Telaah Teori dan Pengembangan Hipotesis}

\section{Teori Atribusi}

Teori atribusi adalah teori yang menjelaskan tentang suatu perilaku seseorang yang dapat dilihat dari sisi internal dan juga sisi eksternal (Yanah, 2013). Sisi internal meliputi sifat, karakter, dan juga sikap, sedangkan sisi eksternal meliputi adanya suatu tekanan yang memaksa seseorang untuk melakukan perbuatan atau perilaku tertentu. Santrock (2003) menjalaskan bahwa teori atribusi merupakan sebuah pandangan untuk menemukan dan memahami sebab-sebab seseorang melakukan perilaku. Selain itu Robbins dan Judge (2013) menyatakan bahwa teori atribusi berfungsi untuk mengamati perilaku seseorang dan menentukan bahwa perilaku tersebut merupakan perilaku yang berasal dari faktor internal atau eksternal. Raharjo (2012) menyebutkan bahwa atribusi merupakan suatu proses yang mana seseorang dapat menarik sebuah kesimpulan tentang faktor apa saja yang dapat mempengaruhi perilaku orang lain atau dirinya sendiri.

Menurut Yanah (2013), atribusi manusia dapat dikelompokkan menjadi tiga jenis, antara lain:

a. Internal atau eksternal

Salah satu penyebab yang berasal dari internal penyebab-penyebab yang berasal dari dalam diri seseorang, sebagai contoh ciri-ciri kepribadian, kecerdasan, sikap, dan kesehatan. Sedangkan penyebab eksternal adalah penyebab yang bukan berasal dari dalam dirinya sendiri, seperti tekanan sosial, aspek sosial, dan keberuntungan.

b. Stabil atau tidak stabil

Tingkat kestabilan yang relatif permanen atau hanya sementara.

c. Dikontrol atau tidak dapat dikontrol

Suasana hati yang dapat dikontrol oleh masing-masing individu, atau sesuatu yang tidak dapat dikendalikan oleh individu.

\section{Pengetahuan Pajak}

Pengetahuan sering kali diartikan sebagai bagian dari bentuk pemahaman atas keilmuan tertentu. Pemahaman atas suatu hal tersebut yang dapat menimbulkan persepsi. Darmajanti (2015) menjelaskan bahwa pengetahuan dapat dibagi menjadi empat bagian yaitu implisit, eksplisit, empiris, dan rasionalisme. Sedangkan pengetahuan pajak merupakan suatu bentuk informasi yang berkaitan dengan pajak dan pengetahuan tersebut dapat digunakan oleh Wajib pajak untuk melakukan, mengambil keputusan, dan membuat strategi tentang hak dan kewajiban dilingkup perpajakan (Sari, 2017). Sedangkan Rahayu (2017) menjelaskan bahwa pengetahuan pajak merupakan kemampuan seseorang untuk memahami peraturan perpajakan sesuai dengan ketentuan yang berlaku serta mengenali manfaat pajak secara umum. Selain itu Ermawati \& Afifi (2018) menjelaskan bahwa pengetahuan pajak adalah besaran pemahaman yang dimiliki oleh seseorang mengenai sesuatu yang boleh dilakukan maupun yang tidak boleh dilakukan berkaitan dengan ketentuan perpajakan. Berdasarkan berbagai pengertian yang sudah dijelaskan diatas maka dapat ditarik kesimpulan bahwa pengetahuan pajak adalah kemampuan seseorang atau Wajib Pajak dalam memahami perpajakan sesuai dengan ketentuan perpajakan yang berlaku. Pengetahuan pajak 
dapat diperoleh melalui pendidikan formal, pelatihan, atau lewat sosialisasi (Damajanti, 2015).

Pengetahuan pajak adalah salah satu faktor atau elemen terpenting dalam menjalankan sistem kepatuhan pajak secara sukarela dan juga menentukan perilaku Wajib Pajak dalam kepatuhan pajak secara self assessment system (Saad, 2014). Hal ini dikarenakan untuk bisa menjalankan self assessment system secara utuh maka Wajib Pajak dituntut untuk bisa menghitung, membayar, dan melaporkan sehingga pengetahuan pajak mempunyai peranan yang sangat penting. Tanpa mempunyai pengetahuan tentang pajak maka prinsip self assessment system ini tidak bisa berjalan secara penuh sehingga kepatuhan pajak juga akan rendah atau tidak maksimal. Pengetahuan tentang perpajakan bisa diidentifikasi menjadi beberapa bagian diantaranya pengetahuan mengenai peraturan perpajakan, pengetahuan tentang sistem perpajakan, serta pengetahuan tentang fungsi perpajakan (Sari, 2017). Berdasarkan penjelasan tersebut maka dapat disimpulkan bahwa seorang Wajib Pajak akan cenderung mematuhi peratuan perpajakan jika mempunyai pengetahuan tentang pajak. Begitupula sebaliknya seorang Wajib pajak cenderung tidak mematuhi peraturan pajak jika meraka tidak cukup mempunyai pengetahuan tentang perpajakan. Terbatasnya pengetahuan tentang pajak dapat menjadi kendala bagi Wajib Pajak untuk menjalankan kewajiban perpajakannya.

\section{Sanksi Pajak}

Sanksi dapat dikatakan sebagai suatu bentuk hukuman atas ketidakpatuhan atau ketidaktaatan terhadap peraturan yang berlaku. Sanksi tersebut merupakan konsekuensi atas suatu perbuatan menyimpang yang telah dilakukan. Terkait dengan perpajakan maka adanya sanksi pajak yang diberikan dapat menjadi suatu bentuk jaminan bahwa peraturan perpajakan akan dipatuhi dan dilaksanakan (Muharani, 2015). Selain itu pemberian sanksi juga dapat menjadi alat pencegahan agar wajib pajak patuh untuk membayar pajak (Mardiasmo, 2011). Berdasarkan penjelasan diatas maka dapat disimpulkan bahwa sanksi pajak merupakan bentuk hukuman atas ketidakpatuhan dalam menjalankan kewajiab perpajakan.
Keberadaan sanksi pajak dapat berfungsi sebagai alat mencegah wajib pajak untuk melanggar ketentuan dari membayar pajak. Sanksi pajak telah diatur di dalam ketentuan perundang-undangan Nomor 28 Tahun 2007 tentang Ketentuan Umum dan Tata Cara Perpajakan. Dengan adanya peraturan yang mengatur maka pemerintah mempunyai dasar untuk memberikan sanksi dengan tegas kepada siapapun yang melanggar atau tidak patuh untuk membayar pajak.

Ini menggambarkan studi terkait sebelumnya sebagai sumber utama. Penggunaan sumber referensi sekunder tidak boleh mendominasi total referensi. Kutipan harus maksimal satu paragraf dan atau inti dari sumber yang dikutip. Ini menggambarkan studi sebelumnya terkait sebagai sumber utama. Penggunaan sumber referensi sekunder tidak boleh mendominasi total referensi. Kutipan harus maksimal satu paragraf dan atau inti dari sumber yang dikutip. Ini menggambarkan studi terkait sebelumnya sebagai sumber utama. Penggunaan sumber referensi sekunder tidak boleh mendominasi total referensi. Kutipan harus maksimal satu paragraf dan atau inti dari sumber yang dikutip (Ghozali dan Fuad, 2017)

Ini menggambarkan studi terkait sebelumnya sebagai sumber utama. Penggunaan sumber referensi sekunder tidak boleh mendominasi total referensi. Kutipan harus maksimal satu paragraf dan atau inti dari sumber yang dikutip. Ini menggambarkan studi sebelumnya terkait sebagai sumber utama. Penggunaan sumber referensi sekunder tidak boleh mendominasi total referensi. Kutipan harus maksimal satu paragraf dan atau inti dari sumber yang dikutip. Ini menggambarkan studi terkait sebelumnya sebagai sumber utama. Penggunaan sumber referensi sekunder tidak boleh mendominasi total referensi. Kutipan harus maksimal satu paragraf dan atau inti dari sumber yang dikutip (Zait dan Bertea, 2017).

Ini menggambarkan studi terkait sebelumnya sebagai sumber utama. Penggunaan sumber referensi sekunder tidak boleh mendominasi total referensi. Kutipan harus maksimal satu paragraf dan atau inti dari sumber yang dikutip. Ini menggambarkan studi sebelumnya terkait sebagai sumber utama. Penggunaan sumber referensi sekunder tidak boleh mendominasi total referensi. Kutipan harus maksimal satu paragraf dan atau inti dari 
sumber yang dikutip. Ini menggambarkan studi terkait sebelumnya sebagai sumber utama. Penggunaan sumber referensi sekunder tidak boleh mendominasi total referensi. Kutipan harus maksimal satu paragraf dan atau inti dari sumber yang dikutip (Luzardi dan Mitchel, 2019)

Ini menggambarkan studi terkait sebelumnya sebagai sumber utama. Penggunaan sumber referensi sekunder tidak boleh mendominasi total referensi. Kutipan harus maksimal satu paragraf dan atau inti dari sumber yang dikutip. Ini menggambarkan studi sebelumnya terkait sebagai sumber utama. Penggunaan sumber referensi sekunder tidak boleh mendominasi total referensi. Kutipan harus maksimal satu paragraf dan atau inti dari sumber yang dikutip. Ini menggambarkan studi terkait sebelumnya sebagai sumber utama. Penggunaan sumber referensi sekunder tidak boleh mendominasi total referensi. Kutipan harus maksimal satu paragraf dan atau inti dari sumber yang dikutip

Sanksi pajak dapat dikatagorikan menjadi dua bagian yaitu sanksi administratif dan sanksi pidana (Muharani, 2015). Sanksi administratif merupakan sanksi yang dijatuhkan kepada wajib pajak berupa pemaksaan pembayaran atas kerugian Negara yang dialami karena ketidakpatuhan dalam membayar pajak atau karena kurangnya jumlah nominal pajak yang harus dibayarkan kepada Negara. Sedangkan sanksi pidana merupakan sanksi yang dijatuhkan kepada wajib pajak berupa kurungan penjara yang prosesnya didahuli dengan persidangan untuk menentukan salah atau tidaknya perilaku tersebut. Penerapan sanksi yang tegas dapat mengarahkan wajib pajak untuk patuh dalam membayar pajak karena jika tidak membayar pajak dan terdeteksi oleh petugas pajak maka wajib pajak harus dikenakan hukuman berupa sanksi administratif dengan melakukan pembayaran tambahan yang besaran nominalnya bisa saja lebih besar dari apa yang harus dibayarkan sebelumnya. Selain itu pemberian hukuman yang besar dapat meningkatkan kepatuhan pajak yang secara substansi juga dapat menekan tingkat penggelapan (Yanah, 2013).

Beberapa penelitian menunjukkan bahwa adanya sanksi dapat meningkatkan kepatuhan wajib pajak dalam membayar pajak. Penelitian tersebut dilakukan diantaranya oleh Rahman (2011), Yanah (2013), dan Muharani (2015).

\section{Modernisasi Sistem}

Modernisasi sistem adalah suatu bentuk inovasi atau pembaharuan yang berfungsi untuk mempermudah wajib pajak dalam mejalankan kewajiban pajak. Penerapan modernisasi sistem juga dapat meningkatkan kepatuhan wajib pajak dikarenakan sistem yang mudah diterapkan akan cenderung diminati dan diimplementasikan oleh penggunya. Perbaikan proses bisnis merupakan faktor penting dari program modernisasi dikarenakan dengan memanfaatkan teknologi informasi maka proses tersebut cenderung akan lebih efektif dan efisien serta lebih cepat, mudah, akurat, dan paperless (Ulum, 2015).

Saat ini sudah banyak sekali bentukbentuk modernisasi sistem yang dikembangkan oleh DJP, antara lain eregistration yang bertujuan untuk melakukan registrasi NPWP secara online, kemudian ada e-SPT, e-Filling, dan e-Payment. Keseluruhan modernisasi sistem ini bertujuan agar wajib pajak lebih mudah untuk menjalankan kewajiban perpajakannya dan bisa dilakukan dimanapun lewat jaringan internet tanpa harus datang ke Kantor Pelayanan Pajak (KPP).

\section{Kepatuhan Pajak}

Kepatuhan sering dikaitkan dengan wujud taat terhadap peraturan atau ketentuan umum yang berlaku. Patuh berarti tunduk terhadap aturan yang ada serta melaksanakannya tanpa melakukan penghindaran. Kepatuhan pajak merupakan suatu kondisi yang mana seseorang bersedia untuk menjalankan semua kewajiban perpajakan. Orang yang patuh terhadap pajak adalah orang yang memiliki kesadaran untuk memenuhi kewajiban perpajakannya sesuai dengan ketentuan yang berlaku tanpa harus melalui suatu pemeriksaan, penyelidikan yang menyeluruh, serta ancaman, dan sanksi (Yanah, 2013). Selain itu kepatuhan pajak dapat didefinisikan sebagai bentuk dorongan motivasi bagi seseorang, kelompok, ataupun organisasi dalam melakukan atau menghindari segala bentuk sanksi sesuai dengan ketentuan peraturan perpajakan yang berlaku (Rahayu, 2006). Oleh karena itu dapat disimpulkan bahwa kepatuhan pajak merupakan suatu kondisi yang mana seseorang mempunyai 
kesadaran serta kemauan untuk taat terhadap peraturan perpajakan.

Kepatuhan dapat dikelompokkan menjadi dua jenis, yaitu kepatuhan secara penuh dengan kesadaran yang tinggi tanpa ada suatu paksaan dari manapun, dan kepatuhan yang masih mempertimbangkan adanya faktor lain, seperti adanya sanksi yang mengharuskan wajib pajak untuk taat terhadap peraturan tersebut. Selain itu dilihat dari sisi praktiknya, kepatuhan pajak dikelompokkan menjadi dua katagori, yaitu kepatuhan administratif yang berkaitan dengan kepatuhan pada saat melakukan pelaporan dan prosedural, serta kepatuhan teknis yang berkaitan dengan kepatuhan dalam menghitung besaran pajak yang akan dibayarkan oleh wajib pajak (Yanah, 2013). Tingkat kepatuhan pajak dapat dipengaruhi oleh pengendalian yang ada di dalam suatu Negara. Jika pengendaliannya kuat maka tingkat kepatuhannya pun menjadi tinggi dikarenakan adanya suatu paksaan yang tersistematis sehingga ini menekan kemungkinan wajib pajak untuk menghindari dari membayar pajak. Begitu pula sebaliknya, jika tingkat pengendaliannya rendah maka ini memunculkan celah atau peluang bagi seorang wajib pajak untuk menghindar dari membayar pajak (Handayani, 2015).

Berdasarkan Peraturan Menteri Keuangan Republik Indonesia Nomor 74/PMK.03/2012 bahwa kepatuhan wajib pajak dapat dijabarkan sebagai berikut:

a. Tepat waktu dalam menyampaikan SPT

b. Tidak mempunyai tunggakan pajak untuk semua jenis pajak, kecuali tunggakan pajak yang telah memperoleh izin mengangsur atau menunda pembayaran pajak

c. Tidak pernah dipidana karena melakukan tindak pidana di bidang perpajakan berdasarkan keputusan pengadilan yang mempunyai kekuatan hukum tetap dalam jangka waktu 5 tahun terakhir

\section{Pengembangan Hipotesis}

\section{Pengetahuan Pajak Terhadap Kepatuhan Wajib Pajak}

Pengetahuan pajak menjadi salah satu faktor atau elemen terpenting dalam menjalankan sistem kepatuhan pajak secara sukarela dan juga menentukan perilaku Wajib Pajak dalam kepatuhan pajak secara self assessment system (Saad, 2014). Hal ini dikarenakan untuk bisa menjalankan self assessment system secara utuh dimana setiap Wajib Pajak dituntut untuk agar melakukan perhitungan, pembayaran, dan pelaporan secara mandiri maka pengetahuan pajak mempunyai peranan yang sangat penting. Tanpa mempunyai pengetahuan tentang pajak maka prinsip self assessment system ini tidak bisa berjalan secara penuh sehingga kepatuhan pajak juga akan rendah atau tidak maksimal. Pengetahuan tentang perpajakan bisa diidentifikasi menjadi beberapa bagian diantaranya pengetahuan mengenai peraturan perpajakan, pengetahuan berkaitan dengan sistem perpajakan, serta pengetahuan yang berkaitan dengan fungsi perpajakan (Sari, 2017). Berdasarkan penjelasan tersebut maka dapat disimpulkan bahwa seseorang akan cenderung patuh terhadap peratuan perpajakan jika mempunyai pengetahuan tentang perpajakan. Begitupula sebaliknya seorang Wajib pajak cenderung tidak patuh terhadap peraturan pajak jika meraka tidak cukup mempunyai pengetahuan tentang perpajakan. Terbatasnya pengetahuan tentang pajak dapat menjadi kendala bagi Wajib Pajak untuk melaksanakan kewajiban perpajakannya.

Beberapa penelitian terdahulu yang berkaitan dengan pengethuan pajak telah dilakukan oleh Rahayu (2006), Winoto (2008), Saad (2014), Muharani (2015), Rahayu (2017), Sari (2017), Ermawati \& Afifi (2018), Indrawan \& Binekas (2018) yang keseluruhannya hasilnya menunjukkan bahwa terdapat pengaruh antara pengetahuan pajak dengan kepatuhan pajak. Akan tetapi penelitian yang dilakukan oleh Darmajanti (2015) menunjukkan hasil yang berbeda yakni pengetahuan pajak tidak mempunyai hubungan dengan kepatuhan pajak.

\section{Sanksi Pajak Terhadap Kepatuhan Wajib Pajak}

Sanksi merupakan suatu hukuman atas konsekunsi perbuatan pelanggaran atau ketidakpatuhan atau ketidaktaatan terhadap suatu peraturan dan ketentuan yang berlaku. Berkaitan dengan pajak, adanya sanksi pajak akan menjadikan suatu aturan pajak akan dipatuhi oleh wajib pajak (Muharani, 2015). Selain itu sanksi pajak berguna sebagai suatu alat pencegahan agar wajib pajak mematuhi kewajiban perpajakan (Mardiasmo, 2011). 
Saksi pajak yang berat akan membuat Wajib pajak cenderung akan berfikir ulang untuk tidak mematuhi kewajiban perpajakannya. Tetapi jika sanksi pajak yang diberikan tergolong ringan maka kecenderungan untuk mengabaikan kewajiban perpanjakannya akan besar.

Penelitian tentang sanksi pajak telah dilakukan oleh Yanah (2013), Handayani (2015), Muharani (2015), Rahayu (2017) menunjukkan hasil bahwa terdapat hubungan anatar sanksi pajak dengan kepatuhan pajak. Sedangkan penelitian yang dilakukan Putra (2017) dan Ermawati \& Afifi (2018) menunjukkan hasil yang berbeda bahwa sanksi pajak tidak mempunyai hubungan terhadap kepatuhan pajak.

Berdasarkan penjelasan diatas maka dapat dirumuskan sebuah hipotesis sebagai berikut:

$\mathrm{H}$ : Sanksi pajak berpengaruh positif terhadap kepatuhan Wajib Pajak.

\section{Modernisasi sistem terhadap kepatuhan wajib pajak}

Modernisasi sistem adalah suatu bentuk inovasi atau pembaharuan yang berfungsi untuk memudahkan seseorang dalam menjalankan kewajiban perpajakannya. Modernisasi sistem juga bisa digunakan dalam meningkatkan kepatuhan wajib pajak. Kemudahan dalam menjalankan sistem tersebut akan menjadi pertimbangan bagi wajib pajak untuk menjalankan sistem tersebut atau tidak. Walaupun sistem yang diterapkan canggih dan moderen tetapi jika penerpannya sulit untuk dilakukan maka wajib pajak akan cederung tidak menjalankan sistem tersebut. Akan tetapi jika sistem yang diterapkan itu mudah untuk dimengerti dan dilakukan walaupun sistemnya hanya sederhana maka orang cenderung bersedia untuk menggunakannya.

Penelitian yang berkaitan sengan modernisasi sistem telah dilakukan oleh Muharani (2015) menunjukkan hasil bahwa modernisasi sistem mempunyai hubungan terhadap kepatuhan pajak. Sedangkan penelitian yang dilakukan oleh Putra (2017) menunjukkan hasil bahwa tidak ada hubungan antara modernisasi sistem dengan kepatuhan pajak.

Berdasarkan penjelasan diatas maka dapat dirumuskan sebuah hipotesis sebagai berikut:
H3: Modernisasi sistem berpengaruh positif terhadap kepatuhan Wajib Pajak.

\section{Metode Penelitian}

Populasi yang digunakan dalam penelitian ini adalah seluruh UMKM yang tercatat di Dinas Koperasi, Usaha Kecil dan Menengah di Kabupaten Sleman. Berdasarkan data yang tercantum dalam website Dinas Koperasi, Usaha Kecil dan Menengah Kabupaten Sleman tercatat bahwa jumlah UKM terdaftar adalah sebanyak 27.139 yang terdiri dari tujuh sektor usaha. Sedangkan jumlah sampel ditentukan dengan menggunakan rumus Slovin.

$$
\begin{aligned}
n & =\frac{27139}{1+27139.10 \%^{2}} \\
& =99,63 \\
& =100 \text { (dibulatkan) }
\end{aligned}
$$

Definisi operasional adalah cara agar suatu variabel dapat diberikan sebuah arti dan variabel tersebut dapat dioperasikan sehingga dapat diukur (Putra dan Basuki, 2015). Berikut beberapa definisi operasional untuk masingmasing variabel beserta pengukurannya:

Pengetahuan pajak adalah kemampuan seseorang atau Wajib Pajak dalam memahami ketentuan perpajakan sesuai dengan peraturan yang berlaku. Variabel ini diadopsi dari Sari (2017) dan diukur dengan menggunakan tujuh indikator yaitu pengetahuan tentang kewajiban pajak, pengetahuan tentang batas waktu pelaporan, pengetahuan tentang NPWP, pengetahuan tentang fungsi pajak, pengetahuan tentang manfaat pajak, pengetahuan tentang sistem pajak, dan pengetahuan tentang tarif pajak yang berlaku. Variabel ini diukur menggunakan skala linkert 4 ruas. Nilai 4 menyatakan sangat setuju dan nilai 1 menunjukkan sangat tidak setuju.

Sanksi pajak adalah sebuah konsekuensi hukuman atas ketidaktaatan dalam menjalankan ketentuan perpajakan. Variabel ini diadopsi dari Putra (2017) serta diukur dengan menggunakan dua indikator yaitu hukuman-hukuman yang akan dijatuhkan oleh Wajib Pajak dan resiko yang terjadi apabila Wajib Pajak melakukan kecurangan pajak. Variabel ini diukur menggunakan skala linkert 4 ruas. Nilai 4 menyatakan sangat setuju dan nilai 1 menunjukkan sangat tidak setuju. 
Modernisasi sistem adalah suatu bentuk inovasi atau pembaharuan yang berfungsi untuk memudahkan seseorang dalam menjalankan kewajiban perpajakan. Variabel ini diadopsi dari Putra (2017) dan diukur dengan menggunakan lima indikator yaitu $e$ registration, e-payment, e-spt, e-filling, dan ebilling. Variabel ini diukur menggunakan skala linkert 4 ruas. Nilai 4 menyatakan sangat setuju dan nilai 1 menunjukkan sangat tidak setuju.

Kepatuhan pajak adalah suatu kondisi yang mana Wajib Pajak bersedia secara mandiri untuk menjalankan kewajiban perpajakannya. Variabel ini diadopsi dari Putra (2017) dan diukur dengan menggunakan empat indikator yaitu, menghitung dan membayar pajak sesuai ketentuan, mengisi SPT dengan benar dan tepat waktu, tidak mempunyai tunggakan pajak, dan tidak pernah dipidana karena pajak. Variabel ini diukur menggunakan skala linkert 4 ruas. Nilai 4 menyatakan sangat setuju dan nilai 1 menunjukkan sangat tidak setuju.

Analisis regresi berganda berfungsi untuk memprediksi secara parsial dan simultan hubungan atau pengaruh lebih dari satu variabel independen terhadap satu variabel dependen. Berdasarkan teori dan penjelasan yang telah dikemukakan sebelumnya, maka persamaan regresinya sebagai berikut:

$$
Y=a+\beta 1 X^{1}+\beta 2 X^{2}+\beta 3 X^{3}+e
$$

\section{Konstanta:}

$$
\begin{array}{ll}
\mathrm{Y} & =\text { Kepatuhan wajib pajak } \\
\mathrm{a} & =\text { Konstanta } \\
\mathrm{X} 1 & =\text { Pengetahuan pajak } \\
\mathrm{X} 2 & =\text { Sanksi pajak } \\
\mathrm{X} 3 & =\text { Modernisasi sistem } \\
\beta 1 \ldots \beta \mathrm{n} & =\text { Koefisien arah regresi }
\end{array}
$$

\section{Hasil Penelitian dan Pembahasan}

Berdasarkan hasil pengujian regresi berganda (lihat tabel 1) maka dapat disimpulkan bahwa persamaan regresi pada penelitian ini adalah sebagai berikut:

$$
\mathrm{Y}=1,260+0,239 \mathrm{X}^{1}+0,157 \mathrm{X}^{2}+0,237 \mathrm{X}^{3}+\mathrm{e}
$$

Tabel 1 Hasil Regresi Berganda

\begin{tabular}{lccc}
\hline \multicolumn{1}{c}{ Variabel bebas } & $\begin{array}{c}\text { Koef. } \\
\text { Beta }\end{array}$ & $\begin{array}{c}\text { t-hi- } \\
\text { tung }\end{array}$ & $\begin{array}{c}\text { Proba- } \\
\text { bilitas }\end{array}$ \\
\hline Konstanta & 1,260 & 5,754 & 0,000 \\
\hline Pengetahuan pajak (X1) & 0,239 & 2,648 & 0,010 \\
\hline Sanksi pajak (X2) & 0,157 & 2,311 & 0,023 \\
\hline Modernisasi sistem (X3) & 0,237 & 3,340 & 0,001 \\
\hline R & & 0,699 \\
\hline R Square & & 0,489 \\
\hline Adjusted R Square & & 0,470 \\
\hline F Hitung & 25,812 \\
\hline Sig. F & 0,000 \\
\hline Sumber: Keluaran dari SPSS 16 & \\
\hline
\end{tabular}

Nilai konstanta (lihat tabel 1) pada penelitian ini adalah sebesar 1,260 yang menunjukkan bahwa jika tidak ada pengetahuan pajak, sanksi pajak, dan modernisasi sistem maka kepatuhan pajak memiliki nilai 1,260 . Selain itu pada variabel pengetahuan pajak memiliki nilai koefisien regresi sebesar 0,239 yang menyatakan bahwa setiap ada penambahan satu satuan (dikarenakan tanda +) maka akan meningkatkan kepatuhan pajak sebesar 23,9\%. Variabel sanksi pajak memiliki nilai koefisien regresi sebesar adalah 0,157 yang menyatakan bahwa setiap ada penambahan satu satuan (dikarenakan tanda +) maka akan meningkatkan kepatuhan pajak sebesar 15,7\%. Sedangkan variabel modernisasi sistem memiliki nilai nilai koefisien regresi sebesar 0,237 yang menunjukkan bahwa setiap ada penambahan satu satuan (dikarenakan tanda + ) maka akan meningkatkan kepatuhan pajak sebesar $23,7 \%$.

Selain itu ketiga variabel independent yakni pengetahuan pajak, sanksi pajak, dan modernisasi sistem mempunyai nilai signifikansi dibawah $p$ value sebesar 0,05 . Nilai signifikansi (lihat tabel 1) untuk variabel pengetahuan pajak adalah 0,010 sedangkan nilai signifikansi untuk variabel sanksi pajak adalah 0,023 dan nilai signifikansi untuk variabel modernisasi pajak adalah 0,001. Berdasarkan nilai signifikansi dari ketiga variabel independent yang memiliki nilai dibawah $p$ value maka hasil pengujian menyatakan bahwa terdapat pengaruh yang signifikan antara masing-masing ketiga variabel (pengetahuan pajak, sanksi pajak, dan modernisasi sistem) tersebut dengan kepatuhan pajak. Sedangkan uji F (lihat tabel 1) pada 
penelitian ini mempunyai nilai signifikansi sebesar 0,000 yang menunjukkan bahwa secara simultan terdapat pengaruh antara pengetahuan pajak, sanksi pajak, dan modernisasi sistem kepatuhan pajak. selain itu pada pengujian determinasi menunjukkan nilai Adj. R2 Square (lihat tabel 1) sebesar 0,470 atau $47 \%$. Hal ini menunjukkan bahwa variabel kepatuhan pajak dapat dijelaskan dengan model regresi pada penelitian ini sedangkan sisanya dapat dijelaskan diluar model regresi ini.

\section{Pembahasan}

\section{Pengetahuan pajak berpengaruh positif terhadap kepatuhan pajak}

Berdasarkan hasil pengujian regresi didapatkan hasil bahwa pengetahuan pajak mempunyai pengaruh positif terhadap kepatuhan pajak. Hal ini disebabkan karena kepatuhan pajak sangat dipengaruhi oleh pengetahuan pajak yang dimiliki oleh masingmasing wajib pajak. Sesuai dengan prinsip self assessment system maka wajib pajak dituntut untuk berperan aktif dalam menjalankan kewajiban perpajakannya masing-masing. Pengetahuan pajak yang setidaknya harus dimiliki oleh wajib pajak antara lain pengetahuan tentang ketentuan dan tata cara perpajakan Pemahaman terhadap peraturan tersebut menjadikan wajib pajak patuh terhadap pajak karena didalam peraturan tersebut memuat tentang hak dan kewajiban dari masing-masing wajib pajak. Selain itu pengetahuan tentang mekanisme pelaporan pajak mulai dari menghitung, menyetorkan, sampai pada melaporkan menjadi faktor kunci dari ketaatan wajib pajak. Bisa dibayangkan jika wajib pajak tidak mempunyai pengetahuan tentang bagaimana pajak itu dilaporkan hingga manfaat apa yang didapatkan dari pajak maka prinsip self assessment system menjadi tidak berjalan dengan baik yang mempunyai konsekuensi ketaatan wajib pajak menjadi rendah.

Hasil penelitian ini sejalan dengan penelitian yang telah dilakukan oleh Rahayu (2006), Saad (2014), Rahayu (2017), Sari (2017), Winoto (2018), Ermawati \& Afifi (2018), Indrawan \& Binekas (2018) yang menunjukkan hasil bahwa pengetahuan pajak mempunyai pengaruh positif terhadap kepatuhan pajak. Tetapi hasil dari penelitian ini bertolak belakang dengan penelitian Darmajanti (2015) dan Muharani (2015) yang menunjukkan hasil bahwa pengetahuan tidak mempunyai pengaruh terhadap kepatuhan pajak.

\section{Saksi pajak berpengaruh positif terhadap kepatuhan pajak}

Berdasarkan hasil pengujian regresi menunjukkan bahwa sanksi pajak mempunyai pengaruh positif terhadap kepatuhan Pajak. Hal ini disebabkan karena wajib pajak cenderung takut jika mendengar kata sanksi. Sanksi yang diterima adalah bagian dari pelanggaran yang telah dilakukan dan biasanya akan mempunyai konsekuensi hukum. Penerapan atau pemberian sanksi kepada seseorang yang tidak patuh untuk menjalankan kewajiban perpajakan bisa menjadi salah satu faktor yang mendukung atau meningkatkan kepatuhan pajak. terlebih lagi bagi pelaku UMKM yang berorientasi pada uang. Pelaku UMKM akan merasa takut jika ditemukan suatu pelanggaran atas ketidakpatuhan terhadap pajak yang mungkin bisa saja mempunyai potensi untuk kehilangan sejumlah uang sebagai bagian dari hukuman atas ketidakpatuhan terhadap pajak tersebut. Hukuman berupa denda atau penjara cukup menjadi dasar pertimbangan bagi wajib pajak untuk tidak lalai dalam kewajiban perpajakan sehingga ancaman tersebut akan manjadi faktor bagi seseorang untuk taat dalam menjalankan kewajiban perpajakannya sesuai dengan ketentuan perundang-undangan yang berlaku di Indonesia.

Hasil dari penelitian ini sejalan dengan penelitian yang telah dilakukan oleh Yanah (2013), Handayani (2015), Muharani (2015), dan Rahayu (2017) yang menunjukkan hasil bahwa sanksi pajak mempunyai pengaruh positif terhadap kepatuhan pajak. Sedangkan penelitian ini bertolak belakang dengan penelitian yang dilakukan oleh Putra (2017) dan Ermawati \& Afifi (2018) yang hasilnya menunjukkan bahwa saksi pajak tidak mempunyai pengaruh positif terhadap kepatuhan pajak.

\section{Modernisasi sistem berpengaruh positif terhadap kepatuhan pajak}

Berdasarkan hasil pengujian regresi menunjukkan bahwa modernisasi sistem mempunyai pengaruh yang positif terhadap perilaku kepatuhan pajak. Hal ini disebabkan karena seseorang beranggapan bahwa sistem pelaporan pajak haruslah yang mudah baik 
mudah dimengerti maupun mudah dijalankan. Bagi sebagaian wajib pajak proses pelaporan pajak mulai dari menghitung, menyetorkan, hingga melaporkan dianggap menyusahkan dan membuang-buang waktu. Terlebih lagi bagi wajib pajak UMKM yang sebagian waktunya dihabiskan untuk urusan bisnis. Kemudahan dalam menjalankan sistem perpajakan dapat membantu juga dalam meningkatkan partisipasi kepatuhan pajak bagi pelaku UMKM. Pada era kemajuan teknologi seperti saat ini sistem pelaporan pajak dituntut cepat tanpa membuat seseorang merasa enggan untuk taat terhadap kewajiban perpajakannya. Hal ini ditunjang juga dengan penerapan prinsip self assessment system yang mewajibkan seorang wajib pajak untuk aktif menjalankan kewajiban perpajakannya masing-masing. Pada waktu lalu proses pelaporan pajak membutuhkan waktu yang lama dikarenakan harus datang dan mengantri di Kantor Pelayanan Pajak. Akan tetapi dengan perkembangan teknologi saat ini proses pelaporan pajak menjadi lebih efektif dan efisien. Seorang wajib pajak yang tidak mempunyai cukup waktu dapat memanfaatkan kemajuan teknologi tersebut untuk melaporkan pajak. Hal ini yang menjadi pertimbangan bagi kebanyakan pelaku UMKM yang tidak mempunyai waktu lebih untuk datang dan mengantri di Kantor Pelayanan Pajak. Selain proses pelaporan pajak yang semakin mudah dan cepat, proses penyetoran atau pembayaran pajak juga semakin mudah. Wajib pajak cukup memanfaatkan kemajuan teknologi dalam penyetoran atau pembayaran pajak, misalkan lewat ATM atau memakai internet banking atau mobile banking. Faktor-faktor itulah yang dapat menjadikan kepatuhan wajib pajak UMKM meningkat.

Hasil dari penelitian ini sejalan dengan penelitian dari Muharani (2015) yang menunjukkan bahwa modernisasi sistem mempunyai pengaruh positif terhadap kepatuhan pajak. Sedangkan penelitian yang dilakukan oleh Putra (2017) menujukkan hasil yang berbeda yakni modernisasi sistem tidak mempunyai pengaruh positif terhadap kepatuhan pajak.

\section{Kesimpulan, Keterbatasan dan Implikasi Hasil Penelitian}

Berdasarkan hasil pengujian regresi dan pembahasan diatas maka kesimpulan dari penelitian ini menunjukkan bahwa terdapat pengaruh positif baik secara parsial maupun secara simultan dari ketiga variabel independen yakni pengetahuan pajak, sanksi pajak, dan modernisasi sistem terhadap kepatuhan pajak. Pengetahuan pajak mempunyai peranan yang sangat signifikan terhadap perilaku kepatuhan pajak karena seorang wajib pajak akan cenderung taat untuk melakukan kewajiban perpajakannya jika Wajib Pajak mempunyai pemahaman dan pengetahuan tentang perpajakan yang berlaku di Indonesia. Begitupula sebaliknya jika seorang wajib pajak tidak mempunyai pemahaman dan pengetahuan tentang pajak maka ketidakpatuhan seorang wajib pajak cenderung lebih tinggi. Selain itu saksi pajak dapat juga mendorong kepatuhan Pajak karena dengan adanya sanksi yang diberikan atas sesuatu yang tidak dijalankan dalam hal perpajakan maka seorang wajib pajak akan memiliki kecenderungan untuk enggan dan akan mempertimbangkan hal tersebut sebagai suatu yang harus diperhatikan. Sedangkan modernisasi pajak juga berperan dalam kepatuhan seorang wajib pajak karena kecenderungan seorang wajib pajak akan lebih senang hati untuk menjalankan kewajiban perpajakannya jika ditunjang dengan sistem pengoperasionalnya mudah untuk dijalankan. Misalkan proses pembayaran dan pelaporan yang mudah untuk dilakukan akan cenderung menggugah minat seorang wajib pajak untuk menjalankan kewajiban perpajakannya.

Penelitian yang telah dilakukan ini memiliki beberapa keterbatasan antara lain pada saat proses pengambilan data yang diperoleh melalui kuesioner maka data kuesioner tersebut tidak bisa semuanya terkumpul dikarenakan kesibukan dari responden yang menyebabkan kuesioner tersebut tidak kembali karena hilang. Selain itu beberapa responden yang sudah terpilih sebelumnya enggan untuk menjadi responden sehingga harus mencari responden yang lain. Hal tersebut menyebabkan pengumpulan data memakan waktu yang sedikit lebih lama.

Saran yang dapat diberikan untuk penelitian selanjutanya adalah sebisa mungkin memastikan bahwa kuesioner yang sudah dibagikan kepada responden sebelumnya bisa terkumpul dengan cara melakukan 
pendampingan langsung pada saat pengisian kuesioner jika kuesinoer tersebut diberikan langsung secara fisik kepada responden. Kemudain melakukan pendampingan atau memberikan penjelasan kepada responden bahwa data yang diisikan tidak akan mempengaruhi apapun termasuk juga tidak akan diketahui oleh petugas pajak sehingga Wajib Pajak sebagai responden tidak perlu khawatir atau takut.

Hasil penelitian ini mempunyai implikasi kepada beberapa pihak diantaranya bagi Direktorat Jenderal Pajak sebagai bentuk evaluasi terkait dengan kepatuhan pajak. DJP bisa melakukan sosialisasi berkaitan dengan penerapan sistem yang digunakan untuk mempermudah proses pelaporan pajak sehingga wajib pajak dapat mengoperasikan sistem tersebut dengan baik dan benar. Selain itu, DJP juga bisa membuat program-program atau strategi-strategi agar Wajib Pajak patuh terhadap pajak dan mau memenuhi kewajiban perpajakan secara sukarela. Selain itu bagi asosiasi pengusaha dapat dijadikan sebagai masukan bagi asosiasi pengusaha untuk bisa menginstruksikan atau mendorong anggotaanggotanya agar patuh terhadap kewajiban perpajakan dengan cara memberikan pendekatan atau melalui sosialisasi kepada anggota. Kemudian bagi peneliti selanjutnya dapat menjadi dasar untuk melakukan penelitian yang lain dengan cara memasukkan variabel-variabel lain diluar variabel yang sudah diteliti mengingat variabel yang sudah diteliti disini baru bisa memprediksi kepatuhan pajak sebesar $47 \%$ sehingga masih banyak variabel-variabel lain yang bisa memprediksi kepatuhan pajak.

\section{Daftar Pustaka}

Ajzen. (1991). The Theory of Planned Behavior. Organizational Behavior and Human Decision Processes, 50(2): 179-211.

Bobek, D.D., Hageman, A.M., \& Kelliher, C.F. (2013). Analyzing the Role of Social Norms in Tax Compliance Behavior. Journal of Business Ethics, 115(3): 451-468.

Budiningrum, E.W. (2014). Pengaruh NormaNorma Sosial Terhadap Perilaku Kepatuhan Pajak Usaha Mikro, Kecil, dan Menengah (UMKM). Tesis, Universitas Gadjah Mada, Yogyakarta.
Damajanti, A. (2015). Pengaruh Pengetahuan Terhadap Kepatuhan Wajib Pajak Perorangan di Kota Semarang, Jurnal Dinamika Sosbud, 17(2): 12-28.

Ermawati, N., \& Afifi, Z. (2018). Pengaruh Pengetahuan Perpajakan dan Sanksi Perpajakan Terhadap Wajib Pajak dengan Religiusitas Sebagai Variabel Pemoderisasi. Prosiding SENDI_U, 1(1): 655-662.

Ghozali, I. (2005). Aplikasi Analisis Multivariat dengan Program SPSS. Semarang, Badan Penerbit Universitas Diponegoro.

Handayani, T. (2015). Pengaruh Etika dan Sanksi Pajak Terhadap Kepatuhan Wajib Pajak (Studi Kasus pada Kantor Pelayanan Pajak Sleman). Skripsi, Universitas Gadjah Mada, Yogyakarta.

Hartono, J. (2008). Sistem Informasi Keperilakuan (Edisi 2), Yogyakarta. Penerbit Andi.

Hartono, J. (2013). Metodologi Penelitian Bisnis: Salah Kaprah dan Pengalaman-pengalaman. Yogyakarta, BPFE UGM.

Indrawan, R., \& Binekas, B. (2018). Pemahaman Pajak dan Pengetahuan Pajak Terhadap Kepatuhan Wajib Pajak UKM. Jurnal Riset Akuntansi dan Keuangan, 6(3): 419-428.

Muharani, N. (2015). Pengaruh Faktor-faktor Eksternal dan Internal Terhadap Kepatuhan Wajib Pajak Orang Pribadi. Skripsi, Universitas Gadjah Mada, Yogyakarta.

Peraturan Menteri Keuangan Republik Indonesia Nomor 74/PMK.03/2012 Tentang Tata Cara Penetapan Dan Pencabutan Penetapan Wajib Pajak Dengan Kriteria Tertentu Dalam Rangka Pengembalian Pendahuluan Kelebihan Pembayaran Pajak.

Putra, A.F., \& Basuki, H. (2015). Pengaruh Faktor Individual dan Situasional Terhadap Niat Melakukan Whistleblowing. Accounting and Bussiness Information System Journal, 12(1): 1-10.

Putra, A.F. (2017). Pengaruh Etika, Sanksi Pajak, Modernisasi Sistem, dan Transparansi Pajak Terhadap Kepatuhan Pajak. Jurnal Akuntansi Indonesia, 6(1): 1-12.

Putra, A.F., \& Osman, A.H. The Compliance of MSME's Taxpayer: Implementation of Theory of Planned Behavior. Journal of Contemporary Accounting, 1(1): 1-10. 
Putri, L.Y. (2014). Pengaruh Sikap, Norma Subjektif, dan Kontrol keperilakuan yang Persepsian Terhadap Kepatuhan Wajib Pajak Orang Pribadi di Kota Yogyakarta. Skripsi, Universitas Negeri Yogyakarta, Yogyakarta.

Rahayu, D.P. (2006). Pengaruh Pengetahuan Perpajakan, Transparansi Belanja Pajak, dan Keadilan Pajak Terhadap Kepatuhan Pajak pada Wajib Pajak di Kota Surakarta. Tesis, Universitas Gadjah Mada, Yogyakarta.

Rahayu, N. (2017). Pengaruh Pengetahuan Perpajakan, Ketegasan Sanksi Pajak, dan Tax Amnesty Terhadap Kepatuhan Wajib Pajak. Akuntansi Dewantara, 1(1): 15-30.

Rustiyaningsih, S. (2012). Faktor-faktor yang Mempengaruhi Kepatuhan Pajak. Widya Warta, 35(2): 44-54.

Saad, N. (2014). Tax Knowledge, Tax Complixity, and Tax Compliance: Taxpayers' View. Procedia - Social and Behavioral Sciences, 109: 1069-1075.

Santoso, S. (2000). Buku Latihan SPSS Statistik Parametrik. Jakarta, PT Elex Media Komputindo.

Sari, V.A.P. (2017). Pengaruh Tax Amnesty, Pengetahuan Perpajakan, dan Pelayanan Fiskus Terhadap Kepatuhan Wajib Pajak. Jurnal Ilmu dan Riset Akuntansi, 6(2): 744760.

Sekaran, U. (2006). Metodologi Penelitian Untuk bisnis (Edisi 4). Jakarta, Salemba Empat.
Sekaran, U., \& Bougie, R. (2013). Research Methods for Business: A Skill-Building Approach (6th Edition), New York, Wiley.

Siahaan, F.O.P. (2013). The Effect of Transparency and Trust on Taxpayers' Voluntary Compliance. GSTF Journal on Business Review, 2, 4-8.

Undang-Undang Nomor 28 Tahun 2007 Tentang Perubahan Ketiga Atas Undang-Undang Nomor 6 Tahun 1983 Tentang Ketentuan Umum dan Tata Cara Perpajakan.

Winardi, R.D. (2013). The Influence of Individual and Situational Factors on Lower-Lavel Civil Servants' Whislteblowing Intention in Indonesia. Thesis, Sheffield Hallam University, England.

Yanah. (2013). The Impact of Administrative Sanction and Understanding of Income Tax Law on Corporate Taxpayer's Compliance. The International Journal of Social Sciences, 12, 55-75.

Yogatama, A. (2014). Analisis Faktor-faktor yang Mempengaruhi Kepatuhan Pajak Wajib Pajak Orang Pribadi (Studi di Wilayah KPP Pratama Semarang Candisuri). Skripsi, Universitas Diponegoro, Semarang.

Winoto, B. (2008). Peranan Pengetahuan Pajak Pada Kepatuhan Wajib Pajak. Jurnal Akuntansi dan Keuangan, 7(2): 196-208. 